\title{
A new species and new records of Oxyethira (Trichoptera:Hydroptilidae) from Minnesota
}

\author{
Margot P. Monson and Ralph W. Holzenthal \\ Department of Entomology, \\ University of Minnesota, \\ St. Paul, Minnesota 55108 USA
}

\begin{abstract}
Males of a new species of microcaddisfly, Oxyethira (Holarctotrichia) itascae, (Trichoptera: Hydroptilidae) from the Lake Itasca region of northern Minnesota are described and illustrated. This represents the first new species of Trichoptera described from the State in nearly twenty years. Fifteen other Oxyethira species are known from the State, including O. (Dampfitrichia) verna Ross and $O$. (Oxyethira) ecornuta Morton, new records for Minnesota and the United States, respectively.
\end{abstract}

Key words: Oxyethira (Holarctotrichia) itascae, caddisflies, endemic, biome.

Fifty-eight of the 280 species of Trichoptera known from Minnesota are members of the family Hydroptilidae and, of these, 16 are species of Oxyethira Eaton. Oxyethira species have been reported from all the major faunal regions of the world, with species records throughout the North American continent. The larvae are typically encountered in standing waters or in lotic habitats where the current is slow. They commonly are located on submerged aquatic plants, where they feed on filamentous algae and diatoms. Some species have been discovered in faster-flowing waters on rocky, mosscovered substrates (Marshall 1979). Larvae of North American Oxyethira may be identified by their exceptionally long, slender meso and metathoric legs, which are at least $2 \frac{1}{2}$ times longer than their prolegs, a long distoventral lobe on the fore tibiae, and very long antennae relative to most other genera in the family. In the final instar, larvae are found within flattened, bottleshaped cases constructed entirely of silk (Wiggins 1977).

Lake Itasca, headwaters of the Mississippi River, is in a region of Minnesota where the northern coniferous forest, eastern deciduous forest, and tallgrass prairie biomes meet (Fig. 1). During 1988 and 1989, adult caddisflies were collected at the edge of three creeks and one small lake near Lake Itasca, as part of a study on the phenology and diversity of the Trichoptera of the region. During the study, a new species of Oxyethira was discovered, which we describe here.

\section{Methods}

Trichoptera were trapped with 15-watt D.C. black lights suspended over pans containing $80 \%$ ethanol and placed at water's edge. Collections were made every two weeks from May to October, 1988 and 1989. Specimens were cleared in $10 \% \mathrm{KOH}$ solution (Ross 1944). Due to their small size, they were examined under compound and dissecting microscopes for identification; illustrations were made with the aid of a drawing tube attachment on an Olympus $\mathrm{BH}-2$ compound microscope. Terminology for genitalic structures follows that of Kelley (1984). Type material is deposited in the University of Minnesota Insect Collection, St. Paul (UMSP), the National Museum of Natural History, Smithsonian Institution, Washington, D.C. (NMNH), and the Illinois Natural History Survey, Champaign, Illinois (INHS), as indicated below.

\section{Oxyethira (Holarctotrichia) itascae Monson and Holzenthal, new species} Fig. 2

Diagnosis. Oxyethira itascae is assigned to the subgenus Holarctotrichia Kelley because of possession by the males of long dorsolateral processes on segment VIII, convergent but separate subgenital processes, and an elongate titillator on the phallus (Kelley 1984). Oxyethira itascae bears some resemblance to $O$. distinctella $\mathrm{Mac}$ Lachlan and $O$. araya Ross, both in the subgenus Holarctotrichia, in the shape of segments VIII 


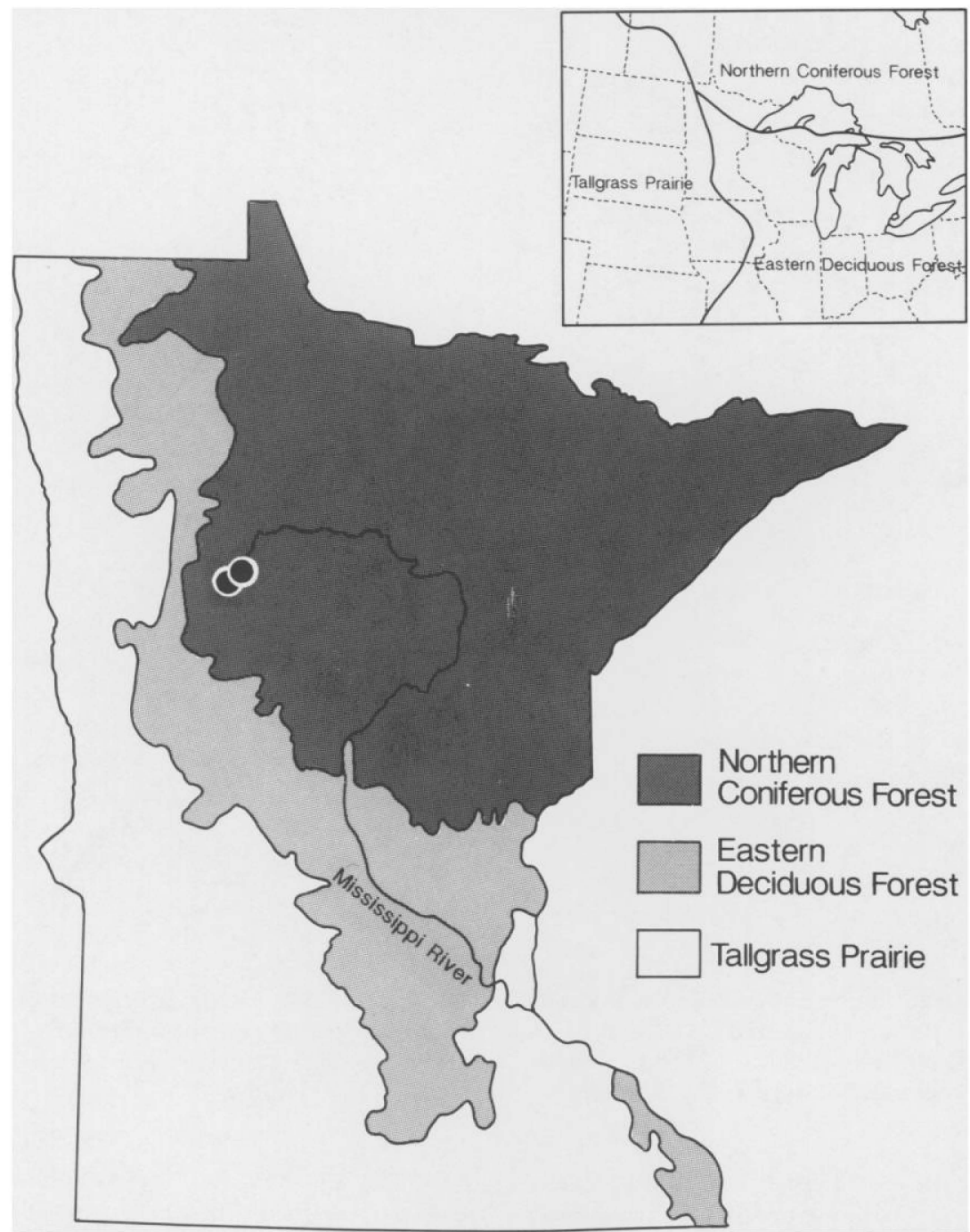

Fig. 1. The three major biomes of Minnesota and the distribution of $O$. itascae, n. sp. Inset: Approximate extent of the same biomes in the Great Lakes region.

and IX. In $O$. araya and $O$. distinctella the posterior margin of segment VIII possesses a triangular configuration similar to $O$. itascae, and the dorsolateral processes are similar to the medial pair of processes in the new species; also, in $O$. araya and $O$. distinctella the truncate dorsal margin of segment IX resembles that of $O$. itascae (Kelley 1986). The presence of two pairs of elongate dorsolateral processes on segment VIII distinguishes the new species from all others in the subgenus in North America.

The new species can be determined using
Blickle's (1979) key to Oxyethira species with slight modifications to his first couplet and the addition of a third choice.

1. 8th tergite produced into a single process on the apicolateral margin ........ 2

- 8th tergite not produced into processes on apicolateral margin ........... 14

- 8th tergite produced into two processes on the apicolateral margin .. itascae, n. sp.

Description. Males. Length 2.8-3.0 mm. Brown in alcohol. Antennae with 25-32 seg- 


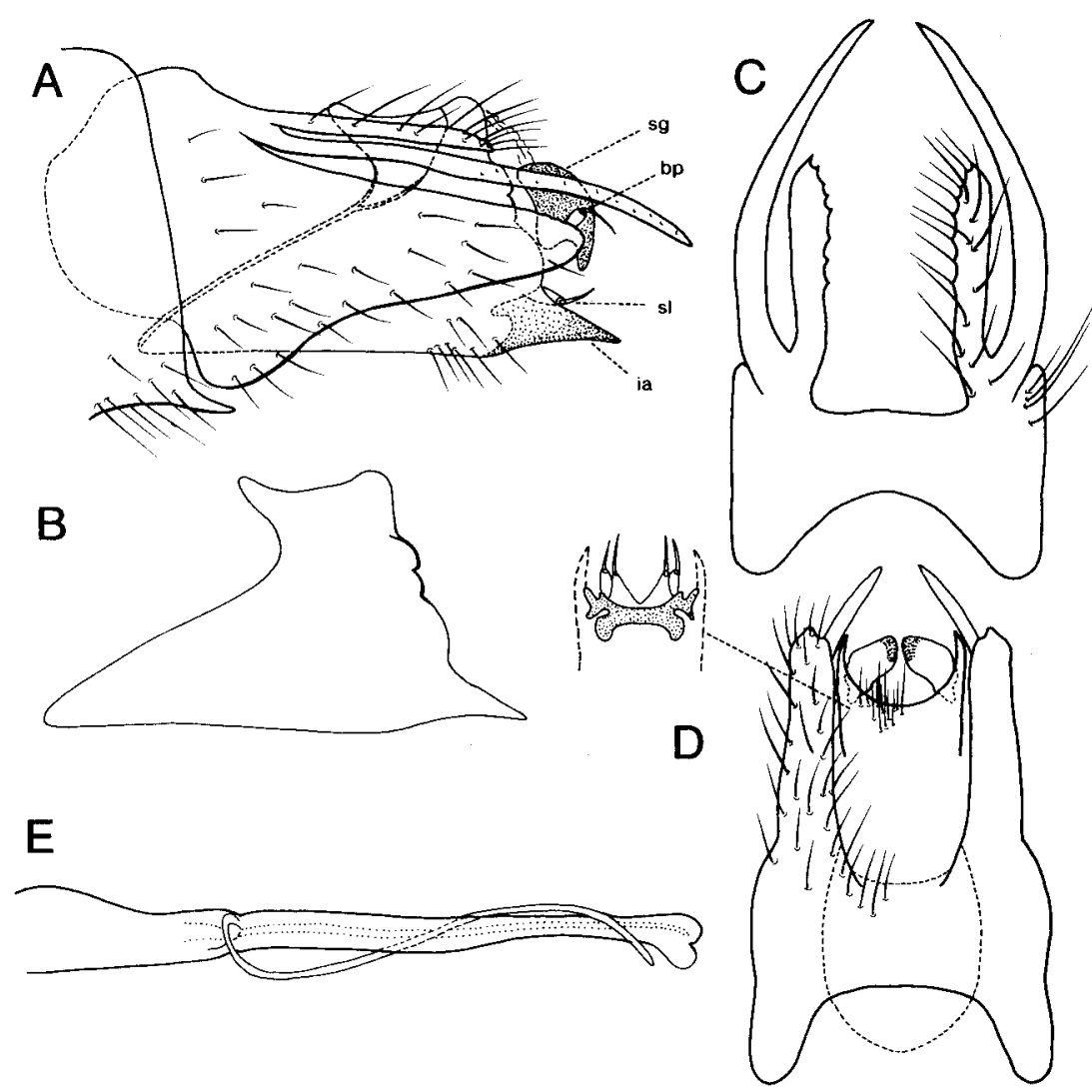

FIG. 2. Oxyethira itascae, new species, male genitalia. A. Segments VII-X, lateral; B. Segment IX, lateral; C. Segment VIII, dorsal; D. Segments VIII and IX, ventral, inset: details of inferior appendages, subgenital processes, and bilobed processes; E. Phallus, dorsal. Abbreviations: $b p=$ bilobed process; ia $=$ inferior appendage; sg = subgenital process; sl = setal lobe.

ments. Genitalia as in Figure 2. Abdominal sternum VII with apicomesal process. Segment VIII roughly triangular in lateral view, with tapering posterior margin; dorsally, with squared posteromesal excavation and two pairs of elongate dorsolateral processes: lateral pair elongate, extending beyond apex of segment IX, slender, acute apically, curved mesally; medial pair about $1 / 2$ length of lateral pair, setose, with apicomesal serrations. Segment IX roughly triangular in lateral view, retracted within VIII; in lateral view, dorsal margin truncate, dorsal and lateral edges semimembranous, except for sclerotized region on posterior margin. Inferior appendages fused to IX with U-shaped configuration in ventral view, mesally setose, tapered to acute apex, slightly curved mesally. Subgenital plate prominent, sclerotized, with conver- gent digitate apices; setal lobes and bilobed processes each with single seta. Segment $X$ entirely membranous. Phallus simple with spiralled titillator.

Females and immatures. Unknown.

Holotype. Male. Minnesota: Clearwater County: Itasca State Park, Nicollet Creek at Wilderness Drive, $47.194^{\circ} \mathrm{N}, 95.230^{\circ} \mathrm{W}$, el. $1500 \mathrm{ft}$., 19.viii.1988, col. M. Monson (UMSP).

Paratypes. Minnesota: Hubbard County: LaSalle Creek at Co. Rd. $40,47.349^{\circ} \mathrm{N}, 95.165^{\circ} \mathrm{W}$, el. 1394 ft., 25.vi.1988, col. M. Monson, 29 males (UMSP); same, except 02.vii.1988, 2 males (INHS); same, except 24.vii.1988, 2 males (NMNH); same, except 26.vii.1988, 4 males (UMSP); same, except 13.viii.1988, 12 males (UMSP); same, except 22.viii.1988, 20 males (UMSP). 
Etymology. Named for Lake Itasca, the headwaters of the Mississippi River. The name Itasca was derived from ver(itas ca)put after the explorer Henry R. Schoolcraft, who in 1832 found the lake to be the true source of the Mississippi River.

Distribution. Known from the type locality and the edge of LaSalle Creek, Hubbard County, in northern Minnesota; flight period is from early June through mid September.

\section{Discussion}

Oxyethira itascae is the first caddisfly to be described from Minnesota since Wiggins' (1975) description of Chilostigma itascae (Limnephilidae) and Etnier's (1968) descriptions of Ceraclea brevis (Leptoceridae, as Athripsodes) and Polycentropus milaca (Polycentropodidae), all believed to be endemic species. The discovery of $O$. itascae at the edge of Nicollet Creek in Itasca State Park is especially interesting because this is also the type locality for Chilostigma itascae, which is known only from adults and represents the single record for that genus outside of Scandinavia and Finland (Wiggins 1977). Nicollet Creek, with its silty bottom and many spring seepage areas, meanders through a wetland meadow surrounded by coniferous forest on its way to join Lake Itasca.

In addition to the new species, Oxyethira ecornuta Morton was collected during the study at LaSalle Creek, also in the Itasca region of Minnesota. This creek, running from LaSalle Lake, has a sand and gravel bottom and empties into a large pool just beyond the collection site, before entering the Mississippi River. This collection represents the first record of O. ecornuta in the United States. This species is Holarctic, with the only other North American record from Ontario, Canada. It is also known from Finland and Sweden (Kelley 1985). Given the distributions of Chilostigma itascae, Oxyethira ecornuta, and Oxyethira itascae, it appears that these are boreal species which may have a particular adaptation to the type of habitat represented in the Itasca region.

The collection of Oxyethira verna Ross from Becker and Hubbard Counties represents a new state record for Minnesota. This Nearctic species is known from many locations throughout the eastern half of North America. Since its oc- currence in Minnesota represents a western limit of its range, it may be a species associated primarily with the eastern deciduous forest, which meets its western limit near the Itasca area.

Ross (1967) states that the ecological characteristics of many caddisflies found only in small streams are a result of the complex interrelationships with the terrestrial communities bordering them. The caddisfly faunas in these habitats are influenced by shade, leaf-fall, precipitation, the climax community, and the relationship between these variables. Correlations have been made between caddisfly phylogenetic and distributional information and the dispersal patterns of some plant groups with which caddisflies have an ecological association (Ross 1967).

The state of Minnesota is at the cross roads of three major biomes, the northern coniferous forest, the eastern deciduous forest, and the tallgrass prairie, which offer habitat variety more diverse than the surrounding states (Coffin and Pfannmuller 1988). The Itasca region in particular is even more closely associated with this merging of biomes, because the coniferous and deciduous forests intermingle in the area, gradually giving way to tallgrass prairie just west of the Itasca region. As a result of ongoing studies and the county biological survey of plants and animals being conducted by the Minnesota Department of Natural Resources, less common species, including relicts, have been found in Minnesota. The distributions of $C$. itascae, $O$. ecornuta, O. verna, and $O$. itascae are further indication that the Lake Itasca region may represent an important confluence in the distribution of the boreal and eastern deciduous forest Trichoptera faunas of North America.

Further evidence of the significance of Minnesota's location at the junction of these biomes is the fact that of the 280 species of caddisflies recorded from Minnesota, 79 , or $28 \%$, are those eastern species whose distribution in Minnesota represents the western limit of their range (Monson and Holzenthal unpublished). Examples include Chimarra obscura (Walker), $\mathrm{Hy}$ droptila armata Ross, Hydatophylax argus (Harris), Lepidostoma bryanti (Banks), and Molanna tryphena Betten. In addition, 30 , or $11 \%$, are those boreal species with the southern limit of their range in North America extending to Minnesota. Among these species are Hydropsyche vexa 
Ross, Polycentropus weedi Blickle and Morse, Hagenella canadensis (Banks), and Ceraclea excisa (Morton). Though the analysis of the biogeography of Minnesota caddisflies is beyond the scope and intention of this paper, it will be interesting to learn if further study of the distribution of plants and animals of the Itasca region reveals other organisms unique to this area or at their range limits in North America.

It is encouraging to note that many of the forests and their watersheds in this area, including the type locality, are protected in State Parks, State Forests, and State Scientific and Natural Areas, the last being established to protect and perpetuate Minnesota's rare and unique natural resources for nature observation, education, and research. In addition, The Mississippi Headwaters Board serves to monitor use and supervise research on this portion of the Mississippi River.

Finally, in addition to the new species and new records, the following Oxyethira species have been recorded from Minnesota (Blickle 1979, Denning 1947, Etnier 1965, 1968): O. (Oxytrichia) aeola Ross, $O$. (Oxytrichia) anabola Blickle, O. (Holarctotrichia) araya Ross, O. (Oxyethira) coercens Morton, O. (Holarctotrichia) forcipata Mosely, O. (Holarctotrichia) michiganensis Mosely, O. (Holarctotrichia) obtatus Denning, $O$. (Dampfitrichia) pallida (Banks), O. (Oxyethira) rivicola Blickle and Morse, O. (Oxyethira) rossi Blickle and Morse, $O$. (Holarctotrichia) serrata Ross, $O$. (Oxyethira) sida Blickle and Morse, and $O$. (Oxyethira) zeronia Ross.

New state records for Oxyethira ecornuta and Oxyethira verna from Minnesota are as follows:

Oxyethira (Oxyethira) ecornuta Morton 1893: 7980, Pl. VI, figs. 1-5, male, (Zoologiska Museum, Helsinki, Finland).

New record. MINNESOTA: Hubbard Coun-

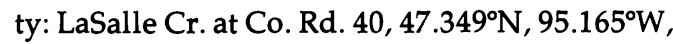
23.vii.1988, el. $1394 \mathrm{ft}$., col. M. Monson, 1 male (UMSP).

Distribution. UNITED STATES: Minnesota; CANADA: Ontario; FINLAND; SWEDEN.

Oxyethira (Dampfitrichia) verna Ross, 1938: 118119, fig. 27, male, (INHS).

New records. MINNESOTA: Hubbard County: LaSalle Cr. at Co. Rd. 40, $47.349^{\circ} \mathrm{N}, 95.165^{\circ} \mathrm{W}$, el. 1394 ft., 25.vi.1988, col. M. Monson, 1 male; same, except 13.viii.1988, 4 males; same, except 22.viii.1988, 1 male; same, except 13.viii.1989, 4 males; same, except 30.ix.1989, 2 males; Becker County: Ottertail R. Mi 162, Hubbel Pond WMA, 16.viii.1982, col. N. Kirsch, 13 males. All specimens in UMSP.

Distribution. UNITED STATES: Alabama, Florida, Illinois, Louisiana, Maine, Michigan, Minnesota, New Hampshire, New Jersey, North Carolina, South Carolina, Tennessee, Texas, Wisconsin; CANADA: New Brunswick, Nova Scotia, Ontario.

\section{Acknowledgements}

We thank Drs. Robert Kelley and Steve Harris for their advice concerning the new species. The University of Minnesota Insect Collection was a valuable resource, and the unpublished checklist of the Trichoptera of North America north of Mexico by Dr. John Morse was also helpful. We thank the University of Minnesota Press and the State of Minnesota, Department of Natural Resources for permission to copy the map of Minnesota biomes (C), State of Minnesota, Department of Natural Resources, 1988). Appreciation is extended to Dr. Bill Miller and Roger Blahnik for reviewing the manuscript. This material is based upon work partially funded by the Nongame Wildlife Program of the Minnesota Department of Natural Resources and the Minnesota chapter of The Nature Conservancy. We gratefully acknowledge this support. This is technical contribution No. 20,407, Scientific Journal Series, Minnesota Agricultural Experiment Station, St. Paul, Minnesota.

\section{Literature Cited}

BLICKLE, R. L. 1979. Hydroptilidae (Trichoptera) of America north of Mexico. Station Bulletin 509. New Hampshire Agricultural Experiment Station, University of New Hampshire.

Coffin, B., AND L. Pfannmuller (editors). 1988. Minnesota's Endangered Flora and Fauna. University of Minnesota Press, Minneapolis.

DENNING, D. G. 1947. New species and records of North American Hydroptilidae (Trichoptera). Psyche 54:170-177.

ETNIER, D. A. 1965. An annotated list of the Trichoptera of Minnesota, with description of a new species. Entomological News 76:141-152.

ETNIER, D. A. 1968. Range extensions of Trichoptera into Minnesota, with descriptions of two new species. Entomological News 79:188-192. 
Kelley, R. W. 1984. Phylogeny, morphology and classification of the micro-caddisfly genus Oxyethira Eaton (Trichoptera:Hydroptilidae). Transactions of the American Entomological Society 110:435-463.

KELLEY, R. W. 1985. Revision of the micro-caddisfly genus Oxyethira (Trichoptera:Hydroptilidae). Part II: subgenus Oxyethira. Transactions of the American Entomological Society 111:223-253.

KELLEY, R. W. 1986. Revision of the micro-caddisfly genus Oxyethira (Trichoptera:Hydroptilidae). Part III: subgenus Holarctotrichia. Proceedings of the Entomological Society of Washington 88:777-785.

MARSHALL, J. E. 1979. A review of the genera of the Hydroptilidae (Trichoptera). Bulletin of the British Museum (Natural History). Entomology series 39:135-239.

MORTON, K. J. 1893. Notes on Hydroptilidae belonging to the European fauna, with descriptions of new species. The Transactions of the Entomological Society of London IV: 75-84.

Ross, H. H. 1938. Descriptions of Nearctic caddis flies (Trichoptera) with special reference to the
Illinois species. Bulletin of the Illinois Natural History Survey 21:101-183.

Ross, H. H. 1944. The caddis flies, or Trichoptera, of Illinois. Bulletin of the Illinois Natural History Survey 23:1-326.

Ross, H. H. 1965. Pleistocene events and insects. Pages 583-596 in H. E. Wright and D. G. Frey (editors). The Quaternary of the United States. Princeton University Press, Princeton.

Ross, H. H. 1967. The evolution and past dispersal of the Trichoptera. Annual Review of Entomology 12:169-206.

Wiggins, G. B. 1975 . Contributions to the systematics of the caddisfly family Limnephilidae (Trichoptera). II. The Canadian Entomologist 107:325336.

Wiggins, G. B. 1977. Larvae of the North American caddisfly genera (Trichoptera). University of Toronto Press, Toronto.

Received: 6 April 1993

Accepted: 17 September 1993 